\title{
MISSION AND FUTURE OF OPEN AIR MUSEUMS IN THE CZECH REPUBLIC

\author{
https://doi.org/10.5817/MuB2018-1-8
}

\author{
EVA KUMINKOVÁ
}

The title of a national conference with international participation fully reflects the aims and goals that the organizers set as starting points for a broad discussion about the purpose, current state and future development of open air museums in our country. Such a large scale discussion occurred only once, at the turn of the 1970s and 1980s, in the course of preparations of the methodology for building open air museums in Czechoslovakia. ${ }^{1}$ Forty years later, experts and open air museum workers decided that the principles introduced in the methodology had to be revisited in light of social changes that the country experienced in the past decades and in relation to contemporary trends in museology and changing needs of the visitors.

The conference took place from 30th January to 2nd February 2018 in the Wallachian Open Air Museum in Rožnov pod Radhoštěm which has the status of a national methodological centre for open air museums. The intention to organize this conference had been anchored in the governmental document Strategy of Development of Museums in the Czech Republic in 2015-2020, ${ }^{2}$ with the Ministry of

1 LANGER, Jiří (ed.). Národopisná muzea $v$ př́rodě. Teoretická a metodická východiska k realizaci. Rožnov pod Radhoštěm: Valašské muzeum v prrírodě, 1981. Available online at http://www.mcmuzeavprirode.cz/ke-stazeni/ langer-pdf.pdf.

2 Koncepce rozvoje muzejnictví $v$ České republice $v$ letech 2015-2020 [online]. Praha: Ministerstvo kultury České republiky, 2015 [cit. 2018-03-27]. Available from www: <https://www.mkcr.cz/ koncepce-rozvoje-muzejnictvi-v-ceske-

-republice-1594.html>.

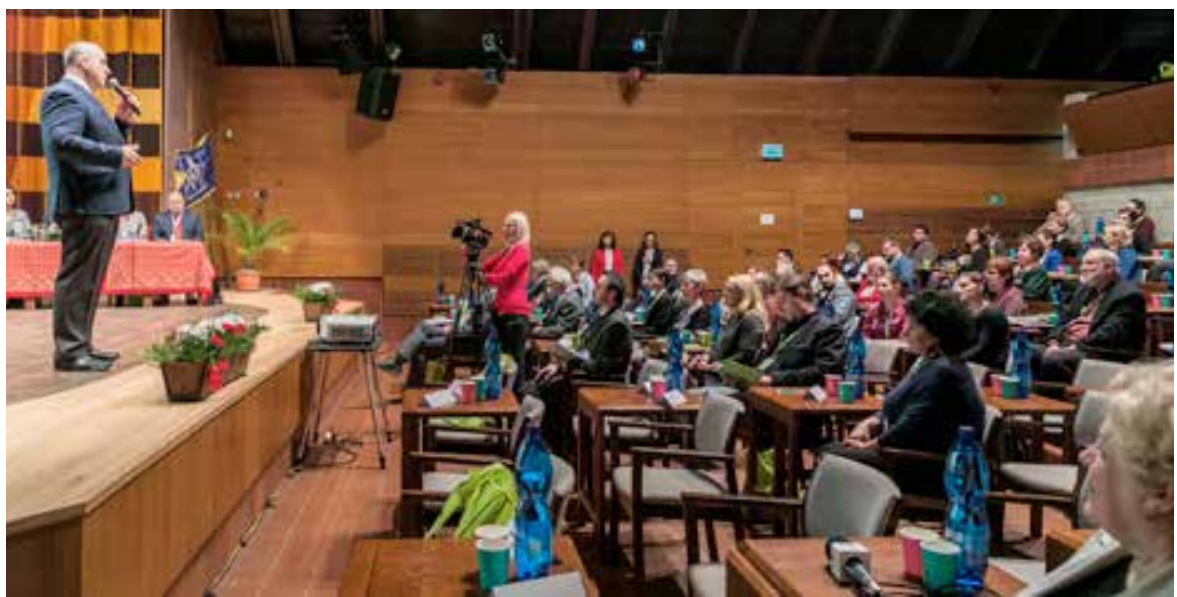

Fig. 1: Opening of the conference (Photo: Jan Kolár̆, Wallachian Open Air Museum)

Culture as the main guarantor of the event. The number of co-organizers and direct partners demonstrates the significance attached to the conference. They included the Wallachian Open air Museum, Ministry of Culture, Czech Association of Open Air Museums, Methodological Centre for Open Air Museums, Czech Ethnological Society, National Institute of Folk Culture, Czech Association of Museum and Galleries and the Czech Commission ICOM (International Council of Museums). The keynote speech was given by the president of the Association of European Open Air Museums (AEOM) and the director of the Swedish open air museum Jamtli Foundation Dr. Henrik Zipsane. Also the Minister of Culture, Dr. Ilja Šmíd, accepted the invitation. On this occasion he awarded Dr. František Ledvinka, the director of the open air museum Zubrnice, with the medal Artis Bohemiae Amicis for his lifelong contribution to the development of the field.

In November 2016, the Wallachian Open Air Museum set up an organizational committee whose task was to decide on the content and overall organization of the conference. The committee consisted of respected experts from different Czech and Slovak open air museums, Ministry of Culture and other experts from the field. Four main themes were recognized as crucial and a series of discussion workshops was organized to prediscuss individual themes, identify problems and decide which issues are most significant and should be included in the conference programme. As another step, main speakers were selected and asked to prepare their talks. Based on the discussions during the workshops, a call for papers was released to invite other experts to apply with their contributed papers and short discussion papers. Especially case studies were welcomed to 


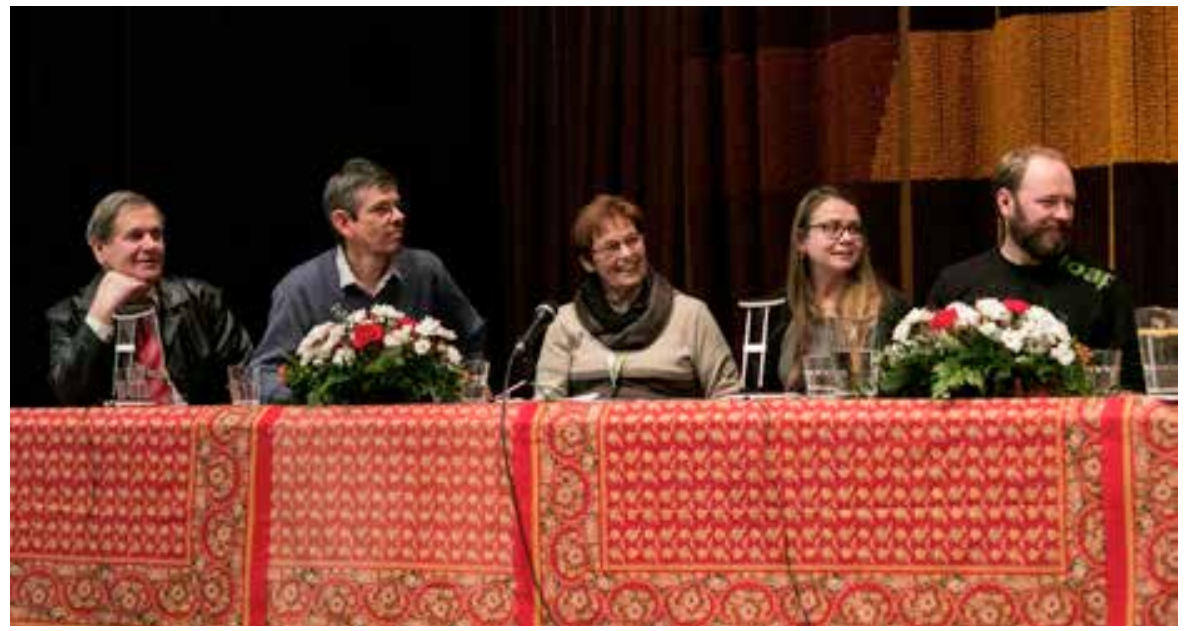

Fig. 2: Speakers from the thematic part Presentation in open air museums (Photo: Jan Kolár̆, Wallachian Open Air Museum)

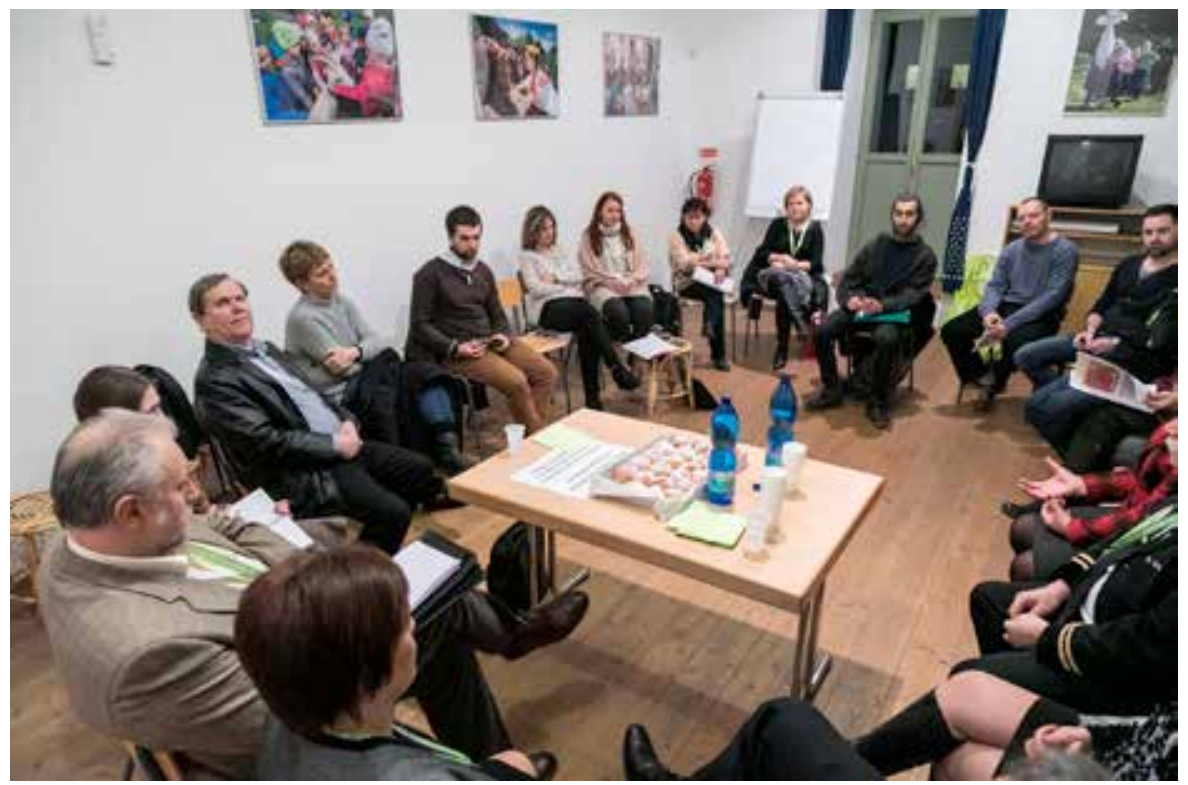

Fig. 3: Working group on legislation (Photo: Jan Kolář, Wallachian Open Air Museum)

complement the theoretical-methodological main speeches. The conference was divided into four thematic parts:

\section{- defining an open air museum} - presentation in open air museums - economy and marketing - open air museums and legislation Each thematic group was moving from theoretical issues to very practical ones. The aim of this thematic division was to respond to the identified needs.

\section{Defining an open air museum}

The first thematic part was built around a thesis, that the definition of an open air museum from 1980s, limited to the ethnographic perspective, was obsolete. Today, many different institutions prefer using the term skanzen. ${ }^{3}$ These institutions

\footnotetext{
3 Czech alternative term for an open air museum originating from the name of the first open air museum in the world - Skansen in Stockholm, Sweden. Skansen was founded in 1891. Some Central European museums use the word in a figurative sense and even include it in their official title.
}

include especially archaeological parks, farmsteads, mills, solitary historic buildings of vernacular architecture, ecomuseums, military fortifications, old mines and other industrial heritage sites. Also these museums were invited to participate in the conference and in the preparatory workshops.

Open air museums see themselves in contrast to traditional museums which have to rely exclusively on individual collection items and lack means of reproduction of their original environment and social relations. On the contrary, open air museums are based on complex theoretical modelling of the original environment which includes buildings, their full furnishing or equipment and also the surrounding landscape. Simultaneously they work with social stratification and relationships. They represent an interpretation of the way of life and culture of a particular society or community in a particular time, in a form of a specialized exhibition uniting time, space, social, historical and natural conditions, and reflecting material as well as intangible aspects of culture. This principle is mirrored in ethnographic museums as well as in other institutions mentioned above. The conference concluded that while in the past open air museums stood in opposition to heritage conservation which was based on different principles, today the working methods of both disciplines are in many aspects closely related. The difference is nowadays seen between open air museums and non-professional attempts to assemble ad hoc collections and to present them as open air museums without respect to the basic pillars of museum work - their scientific nature and their documentary and educational purpose. 


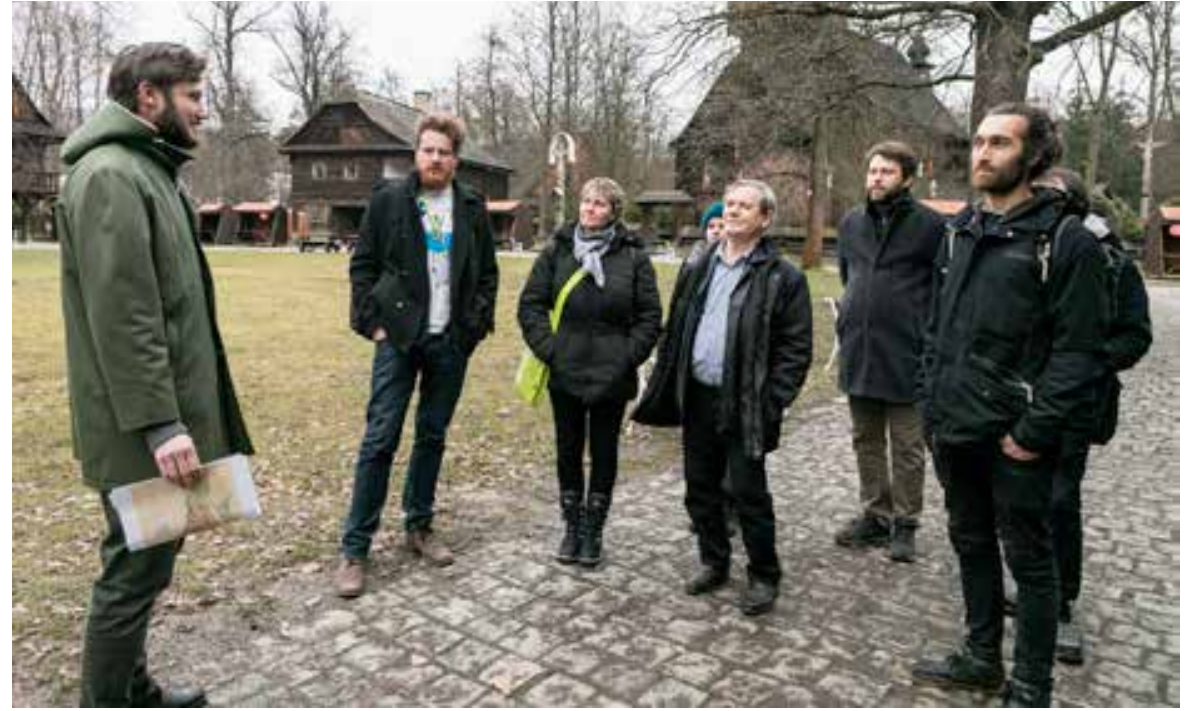

Fig. 4: Rich post-conference programme included guided tour around the museum focused on past approaches to designing and building the Wallachian Open Air Museum and current strategic planning (Photo: Jan Kolář, Wallachian Open Air Museum)

\section{Presentation in open air museums}

No matter how well-conceived the theoretical model of an open air museums is or how valuable is the aspect of cultural heritage presented, the visitor can never appreciate them if they are not interpreted in a clear and accessible way. In this respect, the work of guides and interpreters is indispensable and the success of the museum among visitors more or less depends on them. That is why presentation formed a separate theme within the conference, attracting the largest amount of attention and the highest number of papers.

The conference illustrated how different conditions give birth to different solutions. The theme was opened by looking at presentation as an object of theory. Different types of interpretation and education in open air museums and the role of guides and interpreters, including their proper and necessary training, were further discussed. The contributed and discussion papers touched different types of open air institutions and looked at museum education, volunteering, inclusion of living history in museum projects and many other topics. Specific types of open air museums were also introduced.

The conference had a practical part, too. Participants divided into groups according to their specializations and interests and discussed practical issues as well as worked at improvements of existing definitions. Presentation and interpretation were reflected by two working groups. The first one was supposed to update the typology of open air exhibits while the other group focused on different types of interpretation of these exhibits and the way of life of past generations. The outcomes from these working groups will appear in the updated methodology for open air museums which should be one of the main results of the conference.

\section{Economy and marketing}

When we look beyond the museological aspect, economy and marketing are cornerstones of every cultural institution. However, museums often do not know how to grasp them and how to use them in a profitable and efficient way. This proved to be true already during the preparatory workshop. Especially small museums do not have their staff trained in marketing and sometimes they even lack good quality economic strategies. The main papers focused on three important areas - the relation of products of open air museums to costs and yields, segmentation of visitors and analysis of stakeholders. While large institutions are usually acquainted with these principles, for many participants these presentations could serve as a source of inspiration and new information. The whole section was largely built on case studies and showed that products of open air museums can be identified from the point of view of economy and that the direct and indirect costs can be easily traced. However, interpretation of the collected data is rather complicated. The marketing part highlighted the necessity to involve visitors in the process of assessment of museum's work as well as in strategic planning. Two papers pointed out the importance of proper analysis of stakeholders and their expectations and drawing up a sophisticated strategy for interaction with them. The working group related to the main theme of the section was trying to answer the question where is the boundary between public service and commercialism. This issue turned out to be very ticklish and as it had not been discussed before among open air museums, no final conclusions were made. The group suggested that more time should be devoted to the discussion within the Czech Association of Open Air Museums.

\section{Open air museums and legislation}

The fourth thematic group aspired to open critical issues 
that have been bothering open air museums for decades, partially preventing them from using adequate scientific methods while transferring, reconstructing or rebuilding structures of vernacular architecture. The main papers emphasized the contradiction between the Act on State Landmark Conservation and the Act on the Protection of Museum and Related Collections with the Act on Town and Country Planning and Building Code (Building Act), the Act on Fire Protection and Act on the Protection of Nature and Landscape. This contradiction is based on a premise, that while the heritage and museum conservation primarily cares about protection of the originality, historicity and authenticity of the historic buildings, the building and fire protection acts look at them as at structures which are obliged to meet contemporary norms and technical standards. Speakers in this section talked primarily about the fire protection requirements and their application in open air museums. The main goal of the section was to suggest a wording of an exemption from the Building Act for historic buildings located in open air museums. This text was supposed to be submitted to the lawmakers with a hope that once it could become a part of the Building Act. After a lengthy discussion, the working group realized that no firm definition of an open air museum exists in Czech legislation, which makes application of such exemption impossible. First of all, the Act on the Protection of Museum and Related Collections must be amended and such definition must be included.

Another working group's task was to propose a passport of a historic building located in an open air museum. It should include many detailed information assembled for the purpose of future repairs, reconstructions or maintenance.
This passport will also be included in the updated methodology for open air museums.

The conference aimed to look back at changes in the structure and working methods of open air museums in the Czech Republic which have occurred within the last forty years. As the core of the community is still being formed by ethnographic museums,${ }^{4}$ one of the principal goals of the organizers was to leave the purely ethnographic perspective and invite also other types of open air institutions to share their experience and views. This goal was met only partly. Many different types of institutions were represented, including archaeological parks, industrial heritage sites, solitary farmsteads and mills, ecomuseums, etc. However, it turned out that most experienced experts from ethnographic museums are not yet able to free themselves from their traditional understanding of an open air museum as a reflection of the pastway of life of rural, particularly peasant society. Thus the representatives of certain different types of open air institutions were not able to identify themselves with the concept of an open air museum as it was stipulated, although they use the term skanzen in their title or in their marketing communication. The process of extending the definition of an open air museum will probably need more time to take root and to be accepted by the community.

On the other hand, the participants, active as well as passive, found many intersections in their work and were able to discuss different issues together in depth. These included especially interpretation and different types of presentation,

\footnotetext{
4 See the membership of the Czech Association of Open Air Museums at https://www.vmp.cz/cs/ odborna-cinnost/csmp/clenove-csmp.html.
}

as well as marketing issues. The role of guides and importance of proper interpretation turned out to be one of the crucial issues shared across institutions. The participants also agreed that some of the topics opened at the conference deserve more attention and that the Czech Association of Open Air Museums should initiate further discussions. These included especially marketing and legislation. The outcomes of the conference will be used in the process of drafting the first strategy of development of open air museums in the Czech Republic which has been initiated by the Ministry of Culture and is supposed to be the first national strategic document concerning open air museums in history.

The overall feeling that remained when the conference was over could be described by few words: encounter of generations, humility and respect for the founders, visions for the future, expertise, intelligibility, elimination of social stereotypes, complexity of presentation and interpretation, sharing experience, creative discussion... The Wallachian Open Air Museum has started a dialogue among different segments of the field which had not had a chance to communicate before. The conference showed that there are many themes and issues that are shared and should be developed in future.

\section{Sources:}

LANGER, Jiří (ed.). Národopisná muzea $v$ prírodě. Teoretická a metodická východiska $k$ realizaci. Rožnov pod Radhoštěm: Valašské muzeum v přírodě, 1981.

Koncepce rozvoje muzejnictví v České republice v letech 2015-2020 [online]. Praha: Ministerstvo kultury České republiky, 2015 [cit. 2018-03-27]. Available from www: <https://www. mkcr.cz/koncepce-rozvoje-muzejnictvi-v-ceske-republice-1594.html>. 
Členové ČSMP. In Valašské muzeum v přirodě $v$ Rožnově pod Radhoštěm [online].

Rožnov pod Radhoštěm: Valašské muzeum v Rožnově pod Radhoštěm [cit. 2018-03-27]. Available from www: $<$ https://www.vmp.cz/cs/odbornacinnost/csmp/clenove-csmp.html>.

\section{EVA KUMINKOVÁ}

Wallachian Open Air Museum in Rožnov pod Radhoštěm, Czech Republic 